directing the Institute, and that Karl Przibram is also there. Imbued with the spirit of the Exner School, Meyer was ever ready to place at the disposal of his fellow-workers his stimulating ideas and great wealth of experience as a pioneer and fruitful worker in the field of radioactivity. At the outbreak of war in 1914, and with the backing of the Academy, he successfully appealed for my release as a civilian prisoner of war, and as a result my work in the happy family atmosphere of the Institute continued throughout hostilities. During these years much of the pioneer work on isotopy and on tracer elements (radioactive indicators) was carried out in the Institute (Hevesy and Paneth), and the atomic weights of lead of radioactive origin and of other radioactive elements were accurately determined by Hönigschmid. Several Polish refugees worked in the Institute at that time, including Godfewski, Loria and Patkowski. Work on the counting of radioactive rays was actively pursued, mainly in collaboration with the chief assistant, V. F. Hess, discoverer of cosmic rays (1912). It is of interest to note that two of the members of the Institute later received the Nobel Prize (Hess and Hevesy), the latter also being elected a foreign member of the Royal Society, and quite recently Paneth (now at Durham) has been elected to fellowship of the Society. I shall be ever grateful for the friendly and cordial way in which I was received into the fellowship of the Radium Institute of the Academy, the stimulating and fertile influence of whose members was alone responsible for my being able, as an enemy alien in those eventful years, to publish twenty-three scientific papers, sixteen of which were presented to, and accepted without hesitation by, the Academy for publication in the Berichte.

I have much pleasure in acknowledging the help given me by the vice-president of the Academy, Prof. R. Meister, who supplied much of the information contained in this article. I am also indebted to Akademierat Dr. W. Oberhummer and to my old friend Hofrat Prof. H. Mache for additional information.

ROBERT W. LAwSON

\section{CENTENARY CELEBRATIONS}

The centenary of the Academy was celebrated in Vienna during the week beginning May 11. After the reception of guests in the Academy on the previous evening, the proceedings began on Monday, May 12, with a meeting of the Historical and Philosophical Section. The meeting was opened by the vice-president, Prof. Richard Meister, and after submitting the report of the Section, the general secretary, Prof. Josef Keil, described the work of the Austrian Archæological and Philological Expedition to the Balkans, Asia Minor, Arabia and Egypt. In the evening, there was a performance of Hoffmansthal's "Jedermann" given in the Ronacher Theatre, since the Burgtheater had been damaged by bombing. The meeting of the Mathematical and Science Section was opened on the following day by the president, Prof. Heinrich Ficker, and after the report had been presented by the secretary, Prof. Adalbert Prey, a historical account of the meteorological and geophysical work of the Academy was given by Prof. Ficker.

On May 13 the main ceremonial meeting was held in the great hall of the Academy. The ceiling, which had been damaged by water, has been restored, and this hall, with its magnificent baroque interior, made a fine setting for the distinguished gathering. The president of the Academy, in opening the ceremony and in welcoming the guests, pointed out that the Academy, which once belonged to a great country, now belongs to a small one, but that he hoped it would maintain, on the intellectual level, the characteristics of a great country. The President of Austria, Dr. Karl Renner, who had recently been elected an honorary member, then addressed the meeting, and stressed the importance of the freedom of science and research, and its independence from political influence or ideas. The Austrian Chancellor, Dr. Leopold Figl, then spoke. He referred to the role of Austria in the past as a mediating influence between East and West, and hoped that, in the present times, this could be taken up again. After a speech by the Minister of Education, Dr. Felix Hurdes, the congratulatory addresses from foreign societies were presented. In spite of the difficulties of travel, a number of learned societies sent delegates to attend in person: these included the British Academy (Sir Charles Webster); Cambridge Philosophical Society (Dr. F. P. Bowden); Czech Academy of Sciences (Dr. Viktor Trkal) ; Papal Academy of Sciences, Rome (Prof. Ernst F. Petritsch); Paris Academy of Sciences (Prof. Charles Jacob) ; Polish Academy of Sciences (Prof. Tadeusz Kowalski); Swedish Royal Academy of Sciences (Dr. Orvar Nybelin); Swedish Royal Scientific Society (Prof. Einar Löfstedt); Swiss Academy (Prof. A. von Muralt); and Hungarian Academy of Sciences (Prof. S. Domanovsky). Congratulatory addresses and telegrams were also received from learned societies throughout the world.

The president then announced the election of new members and the award of prizes. Dr. Karl Renner was elected the sole honorary member of the whole Academy. Of the Mathematical and Science Section, J. Radon and W. Schwarzacher were elected full members ; E. Hubble and P. Niggli, foreign honorary members; Sir Henry Dale, A. Ernst, O. Hahn, E. Hertzsprung, H. Pettersson and F. Vening-Meinesz, foreign corresponding members. Of the Philosophical and Historical Section, R. Köstler and K. Mras were elected full members; A. Dempf, I. P. Dengel and C. Rauch, Austrian corresponding members; P. F. Jouguet and Gilbert Murray, foreign honorary members ; and C. Borren, B. Croce, S. Eitrem, H. Kelsen, G. Mercati and C. Samaran, foreign corresponding members. The Grillparzer Prize was awarded to Rudolf Holzer; the Fritz Pregl Prize to Heinz Holter ; the Haitinger Prize to Prof. Berta Karlik, who worked for a time at the Royal Institution, London; and the Rudolf Wegscheider Prize to Prof. Alfons Klemenc. The meeting closed with an account, given by the vice-president, Prof. Meister, of the history of the Academy during the hundred years of its existence ; the first award of the Jubilee Prize was made to him for his "Geschichte der Akademie der Wissenschaften in Wien, 1847-1947".

In the evening, there was a special performance by the State Opera Company of "Figaro", given in the Redoutensaal of the Hofburg. It was a remarkable performance, sparkling with life and gaiety, and it seemed typical of the gay courage of the Viennese and Austrian people that such an art could flourish in spite of the present hardships and the distress and misery of the past few years. On May 14 there was an excursion to the Benedictine Monastery at Melk, and to the Biological Station at Lunz. The Station is beautifully situated on the lake in the hills, and 
the surrounding fields were thick with wild narcissi and spring flowers. On the last day there was a visit to the National Library, followed by a lunch on the Kahlenberg, given by the Mayor of Vienna, and a farewell gathering in the evening in the Rathauskeller.

The visiting delegates naturally found great pleasure in establishing once more normal human relationship with their colleagues, and took the opportunity of visiting their laboratories. Even in the buildings which have not been damaged, the difficulties of carrying on with work are considerable. The problem of fuel for heating the buildings and laboratories throughout the severe Viennese winter is a serious one. Last winter, for example, in the physical and chemical laboratories, no fuel was available; and unless some can be obtained for the coming winter, much of the practical teaching and of the research work must again come to a standstill. No apparatus can be obtained to replace that which has been destroyed or stolen, and the lack of chemicals and the impossibility of getting any is a severe handicap both to teaching and to research. In all departments, the inability to get current publications or books from other countries is considered to be one of the most urgent problems. Action on this is being taken by the British Council and other bodies, but this necessarily takes time, and at the moment there is very little scientific literature available. It was impressive to see how the pursuit of knowledge and the arts, and interest in things of the spirit, took precedence over the material discomfort and struggle of living.

The celebrations were an unqualified success, and, considering the grave material difficulties, it was a remarkable achievement on the part of the secretaries of the Academy and the organisers. There is no doubt that the success owed much to the genial and commanding personality of the president, Prof. Ficker. F. P. BOWDEN

\section{OBITUARIES}

\section{Prof. H. S. Jennings}

THE death of Prof. H. S. Jennings, just after his seventy-ninth birthday, at Santa Monica, California, on April 14, has removed the most venerable figure from the ranks of students of the physiology and genetics of the Protozoa. His passing marks the end of an epoch.

Herbert Spencer Jennings, son of George Nelson Jennings, was born at Tonica (Illinois) on April 8, 1868. He graduated B.S. at Michigan in 1893, and afterwards held several different posts in other American universities. He took the degrees of A.M. (1895) and Ph.D. (1896) at Harvard, and after further wanderings settled at Johns Hopkins. Here he was appointed professor of experimental zoology in 1907, and became director of the zoological laboratory three years later (1910). He occupied this position with distinction until his retirement as professor emeritus in 1938, when he went to prolong his life's work-as a 'research associate'-at the University of California at Los Angeles. His name is therefore especially linked with Johns Hopkins, though he worked in many other places and received degrees and honours from many other American universities. His first wife he married twice-was Louise Burridge, who assisted in the illustration of his publications.
During 1896-97 Jennings studied at Jena under Max Verworn, whose "Allgemeine Physiologie" (first published in 1894) was then arousing much interest among zoologists. Verworn was a pupil of Haeckel, and his book was not inaptly labelled by Rádl "the first - and probably also the last-Darwinistic physio logy". Yet there can be little doubt that Jennings's brief residence in the stronghold of Haeckelism favourably influenced all his subsequent researches. After numerous preliminary papers he finally produced-while at Philadelphia_-his famous "Behavior of the Lower Organisms" in 1906; and this is now generally accepted as a classic of protozoological physiology.

His studies on the physiology of Paramecium gradually led Jennings to investigate variation and heredity in this and other ciliates. A long series of papers-from 1907 until the end of his life-records the results of his accurate and admirable experiments. It is impossible to review these here, but most of his general conclusions will be found in his book "Life and Death, Heredity and Evolution in Unicellular Organisms" (Boston, 1920), his review "Genetics of the Protozoa" (Bibl. Genet., vol. 5, 1929), and the article on "Inheritance in Protozoa" which he contributed to "Protozoa in Biological Research" (edited by Calkins and Summers, 1941 ; reviewed in Nature, vol. 149 , p. $149 ; 1942)$.

Jennings's own labour, and that of his many pupils in similar fields, covered a restricted area but dug very deeply. It is still doubtful, however, how far their findings, in the intensive study of such highly specialized and peculiar organisms as the Ciliata, can be utilized for generalization in the larger domain of genetics. But taken as a whole, the extensive published work of H. S. Jennings does not belie the promise in his forenames: it is all distinguished by a sound philosophical outlook and profound appreciation of the value and scope of scientific method. Consequently, much that he did and wrote will withstand the test of time; and though all his conclusions may not ultimately prove correct, his experiments and his reasonings will undoubtedly endure as a solid basis for the researches of a newer generation.

Clifford DoBell

\section{Mr. G. H. Tipper}

George Howlett TIPPer was born in Kendal in 1881, and educated at Kendal Grammar School and Clare College, Cambridge. He entered the Geological Survey of India in 1902. Apart from service in many parts of India, he went to Burma, the Andaman and Nicobar Islands; he travelled through Baluchistan and across Persia and spent three years in Chitral. During the First World War he served with the Bikanir Camel Corps in Egypt and the Libyan Desert and was in France for a short time. He was eventually recalled to help with the production of mica, a mineral in which he had already specialized. From this time he became keenly interested in its mining and preparation for industry, working at the mines themselves and even learning the technique of trimming and splitting.

Tipper had several severe attacks of malaria while abroad and retired after twenty-five years service in 1927. After visiting mica mines in Rumania and a period of travel in Canada and the United States, he married Dr. C. F. Elam, the well-known metallurgist, and retired to Cambridge with the view of working 